\title{
ANALYSIS OF TABLE EGG PRODUCTION AS A LIVELIHOOD ACTIVITY IN EKITI STATE
}

\section{OLASIMBO MOTUNRAYO APATA}

\begin{abstract}
This paper examines table egg production, as a livelihood activity in Ekiti Stat, Nigeriae Table egg production needs to be economically analyzed to determine its profitability. To be able to achieve this, variables such as socio-economics characteristics of the producers, cost and returns of table egg activity, constraints of production need to be considered. The study was conducted in Ekiti State, Nigeria.Eighty table egg producers who were available at poultry farmers' monthly meeting at the time of data collection were purposively sampled for the study. Questionnaire was used to collect data and this was analyzed using frequency count, percentages, linear regression was also used. The result showed that average age of the respondents was 43 years. All the respondents have formal education. Sixty-one point two percent of respondents were male while $38.8 \%$ were female, most $(81.2 \%)$ of the respondents use deep litter system. The result of regression analysis showed that $30.7 \%$ of the variation in returns from table egg production was explained by the independent variables. These comprised of number of numbers of birds kept (0.262) and type of production system used (0.214), which were significant at 5\% level. Also, hired labour (0.345) was significant at 1\% level. However, family labour (-0.280) had a negative coefficient and significant at 5\% level.
\end{abstract}

Key words: Table egg production, livelihood activity

\section{INTRODUCTION}

Livestock enterprise is an important aspect of agriculture, which can be taken up by people with small or no land capital. Conroy (2005) reported that the majority of the resource-poor households in rural areas own livestock of one type or another and that landless families often own a few goats or chicken and some times one or more large ruminants. These livestock keepers can be in three categories, which include sedentary landless people, who may live in rural or urban areas. The mixed farmers with small farms that are usually rain fed and often located in dry land regions and extensive grazers, whose main livelihood activity is livestock keeping.

Livestock rearing contributes to people's livelihoods in a variety of ways and its contributions tend to be particularly important for poor people because it is a source of cash income from sale of livestock and their products. Poultry production is an important integral livestock enterprise. CBN (1999) reported that there had been increase in the contribution of poultry to Gross Domestic Product in Nigeria from 26\% in 1995 to 27\% in 1999. This significant increase in contribution had been sustained by availability and use of easily available local feed-stuffs (Ojo and Afolabi 2000).

Egg production is a major index of performance of commercial poultry business in Nigeria. Oluyemi and Robert (1979) reported that egg accounts for about $90 \%$ of the income from poultry industry. Poultry egg production enterprise is known to be a very profitable business but if not properly managed, the negligence of the necessary management routine can make the venture unprofitable. Egg is a good source of protein and in addition to this, Jull (1988) reported that it contains vitamins A and D, thiamin and riboflavin, which are present in substantial amount. PAKISSAN (2005) reported that egg had been recognized as one of the best ways of supplying good quality animal protein for human consumption to fulfill their nutrient requirement. Every part of an egg is useful for one thing or the other even the byproduct, the shell can be used for fertilizer (PAKISSAN2005). 


\section{Journal Of Agriculture and Social Research (JASR) Vol. 6, No.2, 2006}

The incessant increasing trend of unemployment in Nigeria stresses the need for alternative income generating activities for the citizens. Livestock rearing especially egg production has been one alternative to serve this purpose. This is because it is less stressful, it does not require large area of land as one of the rooms in an house can be used as pen. Less labour is also required making it possible for landless individuals to take up as income generating activity. Apata and Apata (2005) supported this by reporting that livestock rearing especially egg production serve as an alternative income generating activity to the displaced crop farmers and fishermen in the bitumen belt of Ondo State. Hence there is a need to analyze the economic importance of table egg production in relation to production facilities and the returns from the enterprise. The general objective of the study was to analyze and provide information on the economics of table egg production in Ekiti State. To meet the general objective, the following are the specific objectives: To:-

i. identify the socio-economic characteristics of the table egg producers in Ekiti State;

ii. estimate the cost and returns of table egg production in Ekiti State;

iii. examine the effect of socio-economic characteristics of egg producers on revenue from table egg production in Ekiti State;

iv. know the returns on investment of input on table egg production among egg producer in Ekiti State; and

v. identify the various problems encountered by the table egg producers in Ekiti State.

\section{METHODOLOGY}

A purposive sampling method was used to select eighty table egg producers in Ekiti State. This was because the egg producers that came for monthly egg producers' meetings during the data collection period were selected for the study. A total of 80 table egg producers were selected for the study. Questionnaire was use to collect data on socio-economic characteristics, cost and returns from egg production, methods of table egg production and constraints of table egg production. The data that were collected were analyzed using frequency count and percentages. Linear regression was used to determine relationship between socio-economic characteristics and the revenue from table egg production.

\section{RESULTS AND DISCUSSION}

\section{Socio-economic characteristics of table egg producers}

From Table 1, the result showed that age of table egg producers range from 24 and 60 years and the mean age was 43 years. This showed that most of the respondents are in their middle age and productive years. Sex distribution of the respondents showed that $68.7 \%$ were male while $31.3 \%$ were female. This implies that both male are female alike are involved in table egg production. Majority of the respondents (75\%) are married and 61.3\% practice Christian religion. This showed that table egg production is not in conflict with the major religions in the study area.

Educational qualification of the respondents showed that $42.4 \%$ have post-secondary school qualification. This shows that most of the respondents will be able to read instructions on the drugs and other inputs for the enterprise. In addition to this, they should be able to keep daily necessary records. Farming experience of the respondents ranges from 1 to 25 years and majority of them $(82.6 \%)$ have experience between one and ten years. The cosmopoliteness of respondents showed that all the respondents travel out of their communities to nearby urban areas at least twice a year. This might be due to the fact that they need to travel out of their communities to buy poultry inputs such as poultry birds, feed, drugs and others. 
About $14 \%$ of respondents have table egg production as the only income generating activity while $45 \%$ of respondents are civil servants. Average cost of buying point of lay as at the time of this study was 776.50 naira. Forty-eight point seven percent of respondents keep between 1 and 400 birds. Only $6.3 \%$ of them keep between 1601 and 2000 birds. This implies that table production in Ekiti State is still at small-scale production level. The reason for this might be due to the fact that high proportion of producers are civil servants and they are still in active service. So they keep it as secondary income generating activity. About $42 \%$ of the respondents use family labour while $19 \%$ use both hired and family labour on their farms. This still buttressed the fact that it is been practiced at small-scale level. Average number of birds kept by producers is 590 and average price of a tray of table egg was 344.00 naira as the time of this research.

Table 1: Frequency distribution of Socio-economic characteristics of respondents

\begin{tabular}{|c|c|c|}
\hline Socio-economics characteristis & Frequency & Percentages \\
\hline $\begin{array}{l}\text { Age } \\
\text { Less than } 40 \\
41-50 \\
51-60\end{array}$ & $\begin{array}{l}33 \\
34 \\
13\end{array}$ & $\begin{array}{l}41.4 \\
42.2 \\
16.4\end{array}$ \\
\hline $\begin{array}{l}\text { Sex } \\
\text { Female } \\
\text { Male }\end{array}$ & $\begin{array}{l}25 \\
55\end{array}$ & $\begin{array}{l}31.3 \\
68.7\end{array}$ \\
\hline $\begin{array}{l}\text { Marital status } \\
\text { Single } \\
\text { Married }\end{array}$ & $\begin{array}{l}20 \\
60\end{array}$ & $\begin{array}{l}25.0 \\
75.0\end{array}$ \\
\hline $\begin{array}{l}\text { Religion } \\
\text { Christianity } \\
\text { Islam } \\
\text { Traditional }\end{array}$ & $\begin{array}{l}49 \\
25 \\
6\end{array}$ & $\begin{array}{l}61.3 \\
31.3 \\
7.4\end{array}$ \\
\hline $\begin{array}{l}\text { Educational qualification } \\
\text { Primary education } \\
\text { Secondary edu. } \\
\text { Post secondary edu }\end{array}$ & $\begin{array}{l}13 \\
33 \\
34\end{array}$ & $\begin{array}{l}16.3 \\
41.3 \\
42.4\end{array}$ \\
\hline $\begin{array}{l}\text { Farming experience } \\
1-5 \text { years } \\
6-10 \text { years } \\
\text { Above } 10 \text { years }\end{array}$ & $\begin{array}{l}36 \\
30 \\
14\end{array}$ & $\begin{array}{l}45.2 \\
37.4 \\
17.4\end{array}$ \\
\hline $\begin{array}{l}\text { Cosmopoliteness } \\
\text { Traveling twice } \\
\text { Traveling thrice } \\
\text { Traveling at quarterly } \\
\text { Several times }\end{array}$ & $\begin{array}{l}4 \\
5 \\
28 \\
43\end{array}$ & $\begin{array}{l}5.0 \\
6.2 \\
35.0 \\
53.8\end{array}$ \\
\hline $\begin{array}{l}\text { Number of birds } \\
1-400 \\
401-800 \\
801-1200 \\
1201-1600 \\
1601-2000\end{array}$ & $\begin{array}{l}39 \\
24 \\
9 \\
3 \\
5\end{array}$ & $\begin{array}{l}48.7 \\
30.0 \\
11.3 \\
3.7 \\
6.3\end{array}$ \\
\hline
\end{tabular}

Source: field survey, 2005 


\section{Types Of Production Systems}

The result showed that majority $(81.2 \%)$ of the respondents use deep litter system while $18.8 \%$ use battery cage system. The reason most of them use deep litter system might be due to the fact that deep litter system is less capital intensive in the short-run production period. People that produce table egg at small-scale level usually practice deep liter system. This may be due to the fact that cost of buying battery cages is high and they might not be able to afford it.

Table 2: Frequency distribution of type of table production system used by the producers

\begin{tabular}{|lcc|}
\hline Poultry systems & Frequency & Percentages \\
\hline Battery cages & 15 & 18.8 \\
Deep litter & 65 & 81.2 \\
\hline Total & 80 & 100.0 \\
\hline
\end{tabular}

Source: field survey, 2005

\section{Cost And Return From Table Egg Production}

Cost and return from table egg production. This was estimated for short-run for a period of one year

Table 3: Estimated cost of table egg production for one year

\begin{tabular}{ll}
\hline Table egg production items & Cost in Naira ( $)$ \\
\hline Cost of farm yard manure disposal & 4.10 \\
Cost of feeder for one year & 229.00 \\
Cost of drinker for one year & 221.00 \\
Cost of bird at point of lay & 535.03 \\
Cost of feed for one year & 325.56 \\
Cost of medication & 21.25 \\
Cost of labour & 18.43 \\
Cost of housing & 120.00 \\
Cost of mortality & 10.85 \\
Total & 1486.22 \\
\hline
\end{tabular}

Total cost on one bird was estimated to $\$ 1,486.20$

Revenue that can be generated by one bird was estimated to $=\$ 2,028.10$

Return per bird $=\$ 2,028.10-\$ 1,486.20=\$ 541.90$

$$
\begin{aligned}
\text { Return percentage } & =\frac{541,90}{1,486.20} \\
& =37 \%
\end{aligned}
$$

The result showed that $37 \%$ of total cost of table egg production is the return from the enterprise. This means that the return on investment is the return on every one naira invested and this equals 37 kobo for a period of one year. This finding may be due to the fact that most of the respondents produce using deep litter system, which is cost effective, and less capital investment. This might also be that because the production is still under small-scale production which is easily managed compared with large-scale enterprise.

\section{Effect Of Socio-Economic Characteristics On Revenue From Table egg production}

Linear regression analysis was used to determine this.

$$
\mathrm{R}=0.554 ; \mathrm{R}^{2}=0.307 ; \text { Adjusted } \mathrm{R}^{2}=0.280 ; \mathrm{F}=4.471
$$


Journal Of Agriculture and Social Research (JASR) Vol. 6, No.2, 2006

Table 4: Result of the regression analysis

\begin{tabular}{|l|l|l|l|}
\hline Independent variables & Co-efficient & T- value & $\begin{array}{l}\text { Level } \\
\text { significant }\end{array}$ \\
\hline Hired labour & 0.345 & 3.556 & 0.001 \\
\hline No of birds reared & 0.262 & 2.555 & 0.013 \\
\hline Cost of deep litter system & 0.214 & 2.115 & 0.038 \\
\hline Family labour & -0.280 & -2.177 & 0.033 \\
\hline
\end{tabular}

The result showed that number of bird kept (0.3262), cost of hired labour (0.345) and cost of deep litter system used by table egg producers (0.214) all are significant and have positive influences on revenue from table egg production. This suggests that increases in the use of these variables can increase revenue. However, the use of family labour $(-0.280)$ is significant and has a negative influence on the revenue from table egg production.

$\mathrm{R}$-value was 0.554 , and this explained the correlation factors of all the variables. The $\mathrm{R}^{2}$ value $(0.307)$ showed that $30.7 \%$ of the variation in table egg production, which is directly related to returns on egg sales (Revenue) was explained by all the independent variables $\left(\mathrm{X}_{1}\right.$ to $\left.\mathrm{X}_{10}\right)$. The $\mathrm{R}^{2}$ adjusted value $(0.280)$ showed that if a similar explanatory independent variable was added to the independent variables, the variable would explain the Dependent variable by $28.0 \%$. The overall $\mathrm{F}$ ratio for the linear regression functional form was 4.471 and significant at $5 \%$ and it indicated that the chosen variables made favourable contributions to the variation observed in the returns from egg production. However, there is a negative correlation between revenue and family labour. This means that the more family labour used, the less revenue that would be gotten from table egg production.

\section{Constraints of Table egg production}

The most prominent constraint among the problem encounter by table egg producers is lack of adequate fund which about $29 \%$ of the respondents indicated and 26.2 percent still indicated that lack of adequate fund and poultry pest and diseases are the prominent problems. This calls for the need to extend micro credit facilities to these table egg producers so that they would be able to remain and expand their production as the result showed that there is still need for expansion.

Table 5: Frequency distribution of constraints of table egg production among Respondents

\begin{tabular}{|lcc|}
\hline Constraints of production & Frequency & Percentages \\
\hline Lack of adequate fund & 23 & 28.8 \\
Poultry diseases & 3 & 3.7 \\
Government policy & 8 & 10.0 \\
1 and 2 above & 21 & 26.2 \\
Low demand and sales & 17 & 21.2 \\
High cost of feed \& medication & 8 & 10.0 \\
\hline Total & 80 & 100.0 \\
\hline
\end{tabular}

Source: field survey, 2005 


\section{CONCLUSION}

From the foregone, there is a need to emphasize on table egg production as an alternative to salary job since it is a business that requires less labour and the return from it is faster and high. The producers indicated that lack of adequate fund, poultry diseases and high cost of feed and medication are the prominent problems facing them. The result of the study showed that for every one naira invested on the business, 37 kobo was obtained as the return or profit from it after a period of one year. It is therefore a worthwhile venture. Table egg production can serve as an alternative to salary job among tertiary institution graduates.

\section{RECOMMENDATION}

It is therefore recommended that there should be awareness on the profitability of table egg production as a profitable income generating activity by the school leavers who are looking for one employment opportunity or the other. Government should provide fund or subsidy for such citizens who would like to take up table egg production, as a livelihood activity. Youths in Agriculture Programme should also include table egg production. Government should also provide subsidies to the table egg producers to help them lower the cost and thereby increase profit. Government should provide special loan to the new beginners in the business to enable them establish themselves properly.

\section{REFERENCES}

Apata, O.M and T.G Apata (2005) "Livestock Rearing As An Alternative Income Generating Activity In Bitumen Belt In Ondo State." Edited by Fadairo, F.A.S, S.O.K Fajemilehin and G.E Onibi. Proceedings of The $10^{\text {th }}$ Annual Conference of Animal Science Association of Nigeria held between $12^{\text {th }}$ and $15^{\text {th }}$ September at University of Ado-Ekiti, Nigeria. pp. 560-362.

Central Bank of Nigeria (1999): Annual Report and Statement of Accounts CBN Publications, Nigeria.

Conroy, C. (2005) "Why livestock is important to resource-poor people". Participatory Livestock Research A Guide. Published by Intermediate Technology Development Group (ITDG), Great Britain. pp. 3-5.

Jull, M. A. (1988): Poultry Husbandry .TATA Mc. Graw Hill Publishing Company Limited, New Delhi. pp 429-430.

Ojo, S. O. and Afolabi, J. A. (2000): Economic Analysis of Replacing the Fish Meal Component of Broiler Starter Mash with Gliricidia sepium. Animal Production in the New Millennium, Challenges and Options. Book of Proceeding. Edited by Ukachuckwu, S. N.

Oluyemi, J. A. and Robert, F. A. (1979): Poultry Production in Warmest Climate. Macmillan publishers' Ltd. London and Basingtoke, UK

PAKISSAN.COM (2005): All About Livestock and Poultry. A Publication by Pakissan (C) 2001 - 2005 Pakistan 